\title{
Artificial Islands are not Forest Fragments
}

\section{Bovendorp R*}

Departamento de Ecologia, Universidade Estadual Paulista, Brazil

*Corresponding author: Ricardo Siqueira Bovendorp, Departamento de Ecologia, Universidade Estadual Paulista, CP 13506-900 Rio Claro, SP, Brazil, Email: bovendorp@rc.unesp.br

\section{Opinion \\ Volume 1 Issue 1}

Received Date: March 14, 2018

Published Date: March 21, 2018

DOI: $10.23880 /$ izab- 16000104

\section{Abstract}

This opinion debate the difference between forest fragments and artificial islands. Many species can react differently to forest fragments and artificial islands. The knowledge about species movement help us to understand the effects of forest fragmentation on biodiversity changes.

Keywords: Forest patches; Rodents; Neotropical forests; Animal movement; Exotic species

\section{Opinion}

For many years ecologists naively believe that the balance of extinction and colonization of isolated forest fragments will behave as predicted solely by the island biogeography theory [1]. Ecological changes in artificial islands immersed in large reservoirs have been tempted compare to "real" forest fragments [2,3]. A previously study suggested that small artificial islands will lose all native small mammal species after 40 years of isolation [4]. Although the effects of forest fragmentation on native biodiversity are usually negative, ecologists should be aware that the ecological patterns of extinction and colonization found in artificial islands are far from what is happening in real forest fragments [5]. Forest fragments are immersed in a matrix that is not totally hostile to animal movement [7] and several native small mammals species do occur in human-age modified forest fragments [8], older that the ones reported by other studies [4]. In the Brazilian Atlantic forests, for instance, most of the fragments have exotic species (Mus and Rattus) or even species from open areas, but are far from being "empty forests" of native small mammals [5]. Artificial islands are the exception rather than the rule to help us to understand the effects of forest fragmentation [9] on biodiversity changes [10].

\section{References}

1. Haila Y (2002) A conceptual genealogy of fragmentation research: from island biogeographt to landscape ecology. Ecological Applications 12(2): 321-334.

2. Wright SJ, Gompper ME, Deleon B (1994) Are large predators keystone species in Neotropical forests? The evidence from Barro Colorado island. Oikos 71(2): 279-294.

3. Terborgh J, Lopez L, Nuñez P, Rao M, Shahabuddin G, et al. (2001) Ecological meltdown in predator-free forest fragments. Science 294(5548): 1923-1926.

4. Gibson L, Lynam AJ, Bradshaw CJA, Fangliang HE, Bickford DP, et al. (2013) Near-Complete Extinction 


\section{International Journal of Zoology and Animal Biology}

of Native Small Mammal Fauna 25 Years After Forest Fragmentation. Science 341(6153): 1508-1510.

5. Bovendorp RS, Villar N, de Abreu-Junior EF, Bello C, Regolin AL et al. (2017) Atlantic small-mammal: a dataset of communities of rodents and marsupials of the Atlantic forests of South America. Ecology 98(8): 2226.

6. Pires A, Lira PK, Fernandez FA, Schittini G, Oliveira L, et al. (2002) Frequency of movements of small mammals among Atlantic coastal forest fragments in Brazil. Biological Conservation 108(2): 229 - 237.

7. Puttker T, Bueno A, Barros CS, Sommer S, Pardini R, et al. (2013) Habitat specialization interacts with habitat amount to determine dispersal success of rodents in fragmented landscapes. Journal of Mammalogy 94(3): 714-726.
8. Lira PK, Ewers RM, Banks Leite C, Pardini R, Metzger JP, et al. (2012) Evaluating the legacy of landscape history: extinction debt and species credit in bird and small mammal assemblages in the Brazilian Atlantic Forest. Journal of Applied Ecology 49(6): 1325-1333.

9. Pardini R, Arruda Bueno AD, Gardner TA, Prado PI, Metzger JP, et al. (2010) Beyond the Fragmentation Threshold Hypothesis: Regime Shifts in Biodiversity Across Fragmented Landscapes. Plos One 5(10): 13666.

10. Banks-Leite C, Pardini R, Tambosi LR, Pearse WD, Bueno A et al. (2014) Conserving Brazil's Atlantic forests response. Science 346(6214): 1193-b 